\title{
The Predictive Effects of Self-Esteem, Moral Self, and Moral Reasoning on Delinquent Behaviors of Hong Kong Young People
}

\author{
Christopher Cheng*
}

\author{
Department of Applied Social Studies, City University of Hong Kong, 83 Tat Chee Avenue, Kowloon, Hong \\ Kong
}

\begin{abstract}
While external factors such as family and peers were widely known to be predictive of juvenile delinquency, mixed results were reported regarding the effects of internal (personal) variables such as self-concept and moral reasoning maturity. The present study was to delineate the effects of two variables relating to the self (self-esteem, moral self) and the moral reasoning maturity in predicting delinquency. A sample of 266 young people aged between 17 and 21 were invited to complete a questionnaire composed of global self-concept (self-esteem) scale, moral self scale, moral reasoning test, and a daily behavior checklist. Regression and correlation analyses indicated that moral self and moral reasoning were in general negatively associated with delinquency, but global self-esteem did not have significant linear relation with delinquency. Polynomial contrast tests revealed that moral reasoning and moral self to certain extent had a linear trend with delinquency negatively, but global self-esteem exhibited a curvilinear (U-shape) trend with some but not all delinquent behaviors such as sexual misconduct, drug offenses, gambling. The results were then discussed in the light of self-derogation theory and other relevant theories such as the "threatened ego" and the multidimensional model of self-concept, and hopefully could throw lights to explain the phenomenon for further research.
\end{abstract}

Keywords: Moral reasoning, moral self, delinquency.

\section{INTRODUCTION}

Adolescence is a period of life which many people portrayed as "storm and stress". While the majority of young people can successfully develop to positively functioning individuals, some people are less lucky and may become "social dropouts" such as school dropouts, social deviants or even criminal offenders. As in most urban cities, Hong Kong is of no exception in experiencing the prominent problem of youth delinquency. Stories such as "13-years-old drug addict seeking help" (The Sun 2012), "teenage girl working as dating partners and prostitute for tuition fee" (Apple Daily 2013) are just snapshots of everyday lives in this tiny but populated city. Despite the slightly decreasing trend of overall youth crime rate reported in the last decade (2004-2013) according to the Hong Kong Annual Digest of Statistics (HKSAR 2013), the number of young delinquents who aged 16 to 21 being arrested for non-violent crimes (e.g. shop theft, drug offences, sexual offences, etc) is increasing. Moreover, there are substantial numbers of delinquent acts being excluded from the official statistics if the offenses have not been reported (Broadhurst 2004; Broadhurst, Lee, and Chan 2013). Deviant behavior does not only hinder the learning and positive development of an individual, but also is unhealthy for the society as a whole. It is important to delineate the underlying causes and correlates of youth delinquency in order to step up with

*Address correspondence to this author at the Department of Applied Social Studies, City University of Hong Kong, 83 Tat Chee Avenue, Kowloon, Hong Kong; Tel: +852 3442 8832; Fax: +852 3442 8991; E-mail: sshkc@cityu.edu.hk more preventive measures for the building of a better society.

\section{LITERATURE REVIEW}

Researchers have examined different risk factors or antecedent variables of youth delinquency for many years. Broadly speaking these factors can be classified into internal (self, personal) and external (social, environment) factors, and there were quite consensual findings regarding the effects of external factors such as family, parenting, school experience, peer influence (e.g. Cheung, Ngai, and Ngai 2006; Davis, Tang, and Ko 2004; Ma, Shek, and Lam 2000; Ngai and Cheung 2005; Shek 2004). A large scale study on Hong Kong adolescents revealed that media, family, school, and peer together accounted for more than $56 \%$ of variance in delinquency (Cheung 1997). Similarly, another study in Hong Kong also confirmed that peer, family, and school together accounted for more than $58 \%$ of variance in adolescent delinquency, and delinquent peers had the largest predictive effect (Davis, Tang, and Ko 2004). Warr (1993) also concluded that among various risk factors the peer association with delinquency was most predictive of delinquent behavior. Shaw and Scott (1991) showed that parenting associated with punishment focused or lovewithdrawal was predictive of children's delinquent behaviors. In their study of juvenile offenders, Huey and colleagues (2000) found that good family relations (such as family cohesion, parental monitoring) were associated with decreased affiliation with delinquent peers and delinquent behaviors. In a study of juvenile 
probationers in Hong Kong, Chui and Chan (2011) found that social bond, negative affect, pro-offending attitudes were significant risk factors for recidivism. All in all, research evidence showed that external environmental factors such as peer influence, family, parenting and schooling experiences were significant correlates of delinquency (Cheung, Ngai, and Ngai 2006; Chui and Chan, 2011; Davis, Tang, and Ko 2002; Sun, and Shek, 2009).

However, from another point of view, engaging in delinquent behavior is a personal issue and decision of the individuals themselves. It can be argued that people with high internal risks (e.g. low self-esteem, high aggressiveness) would tend to be more vulnerable to the same negative external factors that other people are also experiencing. Many studies (e.g. Gebhard and Bernard 2007; Hammond and Nicholas 2007; Iselin, DeCoster, and Salekin 2009; Overbeek et al. 2005) have attempted to assess the effects of internal factors such as self-cognitions and self-views (self-esteem, self-efficacy), cognitive maturity (such as moral reasoning development), moral values, emotional problems (depression, anxiety) and so on. Nevertheless, unlike those studies concerning external factors, these studies (about internal risk factors) have accumulated rather inconclusive findings. This study attempts to examine the predictive effects of the cognitions of the self (global self-esteem, moral selfconcept) and cognitive maturity in moral judgment (i.e. moral reasoning).

\section{Self-Concept and Delinquency}

Self-esteem is a popular notion that has always been tagged with some positive connotation. One can often hear teachers, parents, social workers talking about programs to bolster adolescents' self-esteem. However, despite the popularity of the topic both in the practicing fields and the research arena, the role of self-concept (or in general called self-esteem) in delinquency is not yet clearly delineated and the empirical results are still inconclusive. Kaplan (1978) is perhaps among the first pioneers in researching the relationship between self-esteem and delinquency. He proposed the "self-derogation theory" (or termed oppositely "self-enhancement theory") which was based on the human motive to "maximize the experience of positive self-attitudes and to minimize the experience of negative self-attitudes" (Kaplan 1980:8). Kaplan's self-derogation theory links low self-esteem to many adolescent problems, which suggests that adolescents with self-derogation or low self-esteem are more likely to turn to delinquent behaviors or peer associations to enhance their self-esteem. According to Kaplan $(1978,1980)$, adolescents with low self-esteem have always undergone unsatisfactory experiences in the conventional society and these experiences have created painful feelings of doubt about their self-worth. Seeking to alleviate these painful feelings, the child tends to adopt the role of others and guide his own behavior by perceiving, evaluating, and expressing attitudes towards himself and others in such a way that he feels good, i.e. maximizing positive self-attitudes and minimizing negative self-attitudes to satisfy his personal needs. Thus, under the notion of self-esteem motives, adolescents with low self-esteem are urged "internally" to engage in deviant behavior aiming at boosting their self image (for example, I am able to attract friends, or I don't need to rely on you, I have the ability to act on my own). Adolescents with low selfesteem are in greater self-enhancing need and are more vulnerable to others' expression of rejection or experience of failures. Hence, low self-esteem adolescents will be more upset when they experience failure and rejection and will be more prone to adopt deviant behavior.

Subsequent to Kaplan's postulation of the selfderogation model, a number of studies have found some empirical support for the notion of a negative association between low self-esteem and delinquency (e.g. Donnellan et al. 2005; Kaplan, Johnson, and Bailey 1986; Owens 1994; Shin and Yu 2012). Using a longitudinal design, Kaplan and colleagues showed that negative self beliefs (e.g. rejection by teacher, rejection by parents, self derogation attributes and so on) were positively correlated with delinquent behaviors. In a more recent study, after controlling for some potential confounding variables Donnellan and colleagues (2005) found a robust relation between low self-esteem and externalizing problems and delinquency. The linkage held for different age groups, different measurement methods of self-esteem, and after controlling for potential confounding variables. By comparing the effects of positive and negative selfviews, Owens (1994) showed that the effect of selfdeprecation on delinquency was significantly stronger than that of positive self-views. This suggested that negative beliefs about oneself played a stronger role in leaning toward delinquency than did an erosion of positive self-attitudes. Shin and Yu (2012) found that students who could not gain teachers' or parents' assurance were more likely to seek acceptance from their peers by involving in delinquent behaviors. In a 
study of possible selves and negative health behaviors during early adolescence, Aloise-Young and colleagues (2001) suggested that adolescent cigarette smoking and alcohol use were related negatively to the number of positive expected selves and the balance between expected selves and feared selves.

However, empirical results were not consensual in delineating the relation between self-concept and delinquency as Kaplan and colleagues predicted (e.g. Brownfield and Thompson 2005; Jang and Thornberry 1998; Wells and Rankin 1983). Contrary to the prediction of self-derogation theory, Jang and Thornberry (1998) found that low self-esteem did not increase associations with delinquent peers or predict delinquent behavior as Kaplan and his colleagues predicted. However, they did find that delinquent associates had significant self-enhancing effects on later self-esteem. Wells and Rankin (1983) also observed that the effect of self-esteem on subsequent delinquent behavior was rather weak. Similarly, Owens (1994) did not find significant evidence to support the hypothesis that self-deprecation would have a positive effect on delinquency, and that delinquency would have a negative effect on self-deprecation. Furthermore, while the association between low self-esteem and delinquency was questioned, some studies reported positive instead of negative association between delinquency and self-concept. In a study Brownfield and Thompson (2005) showed that self-concept could moderately predict delinquency, and this predictive power of self-concept on delinquency remained strong even after Social Control Theory measures (i.e. attachment, commitment and belief) was added to the regression model. However, one should note that the beta coefficients of self-concept in both regression models were positive, implying that higher self-concept was associated with more delinquency. Adopting a multidimensional model of self-concept, Leung and Lau (1989) found that delinquency had a positive instead of negative correlations with social self-concept and physical self-concept, but academic self-concept had a negative effect on delinquency. Moreover, there were studies pointing out that the relation between selfesteem and delinquency could be an indirect one which was mediated by maladaptive achievement strategies, school adjustment, and internalizing problems such as depressive symptoms (Aunola et al. 2000).

Some other research found that this relationship could be bi-directional and dynamic in nature. In other words, there could be countervailing reciprocal relationship between self-esteem and deviant behaviour (Rosenberg, Schooler, and Schoenbach 1989). Rosenberg and colleagues (1989) found that low self-esteem fostered delinquency and that continuing engaging in delinquency could enhance selfesteem. In a recent study Shin and Yu (2012) also noted that young people's self-esteem could be enhanced once their problem behaviors had received peer support, and their increasing self-esteem could further promote their engagement in problem behavior. Putting together, it was undeniable that empirical results supporting the notion of low self-esteem being predictive of delinquency were rather inconsistent.

\section{Moral Reasoning and Delinquency}

From a cognitive developmental perspective, Piaget (1965) suggested that the ability of moral reasoning was in accordance to one's cognitive development. Moral reasoning ability was determined by the cognitive capability of an individual in understanding and respecting universally acceptable solutions to moral issues. Kohlberg $(1969,1984)$ expanded the work of Piaget on moral reasoning to stages of adolescence and adulthood. He believed that moral reasoning ability develops with age in ascending order: (1) preconventional morality, in which actions are classified as right or wrong based on the anticipated consequences such as punishment or disapproval; at this stage rules and social expectations are imposed from the outside by authority figures; (2) conventional morality, in which actions are evaluated in the basis of comments from other people, and the self has internalized these rules as ruling principles; and (3) post-conventional morality, in which the self and social rules and expectations are differentiated, higher-order moral values and ethical principles are used to evaluate individuals' actions. Kohlberg also suggested that moral reasoning is an important factor that provides unity in making the moral judgment and decision for moral action. Hence, according to the cognitive developmental theory, young people who are morally less mature should be more likely to engage in delinquent behaviors.

More than fifty studies have studied the link between moral reasoning and delinquency since Piaget (1965) and Kohlberg (1969) proposed the cognitive stages of moral development. Two meta-analyses on moral reasoning and delinquency were conducted in the last two decades, one by Nelson and colleagues (Nelson, Smith, and Dodd, 1990) and one by Stams and colleagues on 50 studies (including 11 of the 15 studies by Nelson and colleagues) (Stams et al. 2006). In general, there were consensual findings supporting a 
negative link between moral reasoning and delinquency, especially among male offenders, older rather than younger delinquents. While some moderating effects of variables such as socioeconomic status, culture, gender, age, and intelligence were reported in some studies, the main effect of moral reasoning was shown to be largely robust even after controlling for these moderating variables. To conclude, delinquents were reported to show a lower level of moral reasoning development than the nondelinquents. Some studies conducted after the Stams and colleagues' (2006) meta-analysis also reported this phenomenon. For example, in a study comparing the normal population and male offenders from youth correctional institutions, offenders' moral reasoning development was significantly less mature than the control group even when age was controlled (Chen, \& Howitt, 2007). Using a longitudinal design Raaijmakers, Engels, and Van Hoof (2005) found that there was significant though modest negative relationship between moral maturity and delinquency. However, there were other studies questioning the role of moral reasoning in delinquency but highlighting the role of moral values or moral self (self views or beliefs about moral values). When variables such as $I Q$, social background were controlled, Tarry and Emler (2007) found that moral values were found to be more predictive of delinquency than a structural measure of moral reasoning. Similarly, in another study it was found that moral reasoning had very weak direct relation with delinquency and it was observed only among male delinquents (Beerthuizena, Brugmana, \& Basingerb, 2013). By comparing the effects on antisocial and pro-social behaviors, Johnston and Krettenauer (2011) found that moral self could predict anti-social behavior but not pro-social behavior. Hence, it seems logical to argue that one's self views or self evaluation in the moral domain (moral self) should be an integral part of the person's internal factors that may have effect on delinquent acts.

To summarize, there is overall evidence suggesting a linear negative relation between moral reasoning and delinquency, yet it is not clear whether moral reasoning or other self-beliefs (such as self-esteem or moral self) should have more predictive validity on delinquency. Prior studies in this area had seldom investigated the effects of moral reasoning with other variables such as self-esteem and moral self being considered simultaneously. The present study was to examine the relative importance of these three factors in explaining delinquency. Besides, even though previous studies have found some linkage between delinquency and moral reasoning and self-esteem, it is not known whether such linkage should be similar in extent and in pattern across different kinds of delinquent behaviors.

\section{METHOD}

\section{Participants}

A total of 266 young people (156 males, 110 females) aged between 17 and $22(M=18.47, S D=1.77)$ were recruited using purposive sampling method. In order to recruit the target samples, research assistants had visited a public secondary school, two social centers and other public arena which were populated with young people (such as playgrounds, bars and cafes). The research assistants invited targeted participants for the study and obtained their informed consent. After ensured of confidentiality and anonymity, the participants completed the questionnaire individually using pencil-and-paper method. All data were entered to and analyzed with SPSS v.19. The demographics were captioned in Table 1.

Table 1: Demographic Statistics of the Respondents

\begin{tabular}{|c|c|c|}
\hline Characteristics & $\begin{array}{c}\text { Male } \\
(n=154)\end{array}$ & $\begin{array}{c}\text { Female } \\
(n=112)\end{array}$ \\
\hline \multicolumn{3}{|l|}{ Age } \\
\hline 17 & $59(22.18 \%)$ & $39(14.66 \%)$ \\
\hline 18 & 47 (17.67\%) & $39(14.66 \%)$ \\
\hline 19 & $15(5.64 \%)$ & $17(6.39 \%)$ \\
\hline 20 & $13(4.89 \%)$ & $4(1.50 \%)$ \\
\hline 21 & $13(4.89 \%)$ & $7(2.63 \%)$ \\
\hline 22 & $7(2.63 \%)$ & $6(2.26 \%)$ \\
\hline \multicolumn{3}{|l|}{ Educational level } \\
\hline Form 5 & $11(4.15 \%)$ & $1(0.38 \%)$ \\
\hline Form 6 & $75(28.3 \%)$ & $52(19.62 \%)$ \\
\hline Form 7 & $32(12.08 \%)$ & $30(11.32 \%)$ \\
\hline Associate degree & $8(3.02 \%)$ & $7(2.64 \%)$ \\
\hline Year 1 & $4(1.51 \%)$ & $8(3.02 \%)$ \\
\hline Working & $17(6.42 \%)$ & $7(2.64 \%)$ \\
\hline Unemployed & $7(2.64 \%)$ & $6(2.26 \%)$ \\
\hline \multicolumn{3}{|l|}{ Place of birth } \\
\hline Hong Kong & $131(49.80 \%)$ & $96(36.50 \%)$ \\
\hline Mainland China & $19(7.22 \%)$ & $13(4.94 \%)$ \\
\hline Others & $2(0.76 \%)$ & $2(0.76 \%)$ \\
\hline
\end{tabular}

\section{Instruments}

Respondents were to complete a questionnaire consisting of four scales (self-esteem, moral self, moral 
reasoning, daily behavior checklist) and demographic variables (age, sex, education). All items were presented in the Chinese language and were selfadministered using paper and pencil.

\section{Self-Esteem and Moral Self-Concept}

The General Self (GS) (8 items) and Moral Self (MS) (8 items) subscales of the Chinese Adolescent Self-Esteem Scales (CASES) (Cheng \& Watkins, 2000) were used to measure respondents' global self-concept (self-esteem) and moral self-concept of the respondent respectively. Format of responding was on a 5-point Likert scale, from 0 (Never) to 4 (Always). The CASES has been proven to possess very strong psychometric properties both in terms of reliability and construct validity (e.g. Cheng \& Watkins, 2000; EMB, 2003). Both the GS and MS subscales possessed high internal consistency in the present study, Cronbach's alpha coefficients at .876 and .843 respectively.

\section{Daily Behaviour Checklist (DBC)}

A behavior checklist was constructed with reference to relevant literature (e.g. Baldry \& Farrington, 2000; Lo, Cheng, Wong, \& Rochelle, 2011; Wong \& Cheng, 2000) and ideas generated from a focus group of young people $(\mathrm{N}=8)$. It had 44 items covering both positive/neutral behaviors (14 items) and delinquent behaviors (30 items). The delinquent behaviors covered different kinds of negative behaviors or offenses, including gambling, violence, property offense or thefts, gangsters, sexual misconduct, and drug offenses. Participants were asked to report how frequently they had committed each of the acts over the past three months on a 5-point scale (from 1=never to 5 =always). The overall delinquency score was the summation score of the 30 delinquent items (i.e. excluding the neutral or positive items). High internal consistency reliability was found by Cronbach's alpha (.903).

\section{Moral Reasoning Test (MRT)}

The test was adapted by Jou (2004) for Chinese speaking people in Taiwan (Jou, 2004: 102-108) based on Piaget's cognitive development theory (Piaget, 1965) with consideration of Rest's Defining Issues Test (DIT; Rest, 1975). MRT was designed to test the moral reasoning maturity of the individual. It included 9 dilemmas in which each dilemma had two or three choices for the respondent to judge which one was correct. Each dilemma represented a theme in the individual's cognitive construction of moral reasoning, including subjective responsibility on stealing (item 1) and on lying (item 2), parent/child and peers reciprocal punishment (items 3 and 4), personal responsibility (item 5), connoted justice (item 6), distributed justice (item 7), equality (item 8 ), and surrender (item 9). As the MRT was a test of moral maturity or moral reasoning development but not a measure of trait, its contents were diverse and in principle not subject to internal consistency reliability test. A test-retest reliability should suffice the purpose of checking the reliability, however due to the research design of the present study (which is cross-sectional) such index could not be obtained. Nevertheless, the test showed good validity in previous studies (e.g. Jou, 2004; Wong, Cheng, Leung, \& Ma, 2010) and in the present study.

\section{RESULTS}

Female respondents reported higher moral selfconcept than males did $(t=-4.56, p<.01$, Cohen's $d=$ $-.56)$, but there was no significant gender difference in moral reasoning maturity or in self-esteem (Table 2). As predicted, gender difference in delinquency was found, males $(M=47.37)$ showed higher overall delinquency than females did $(M=38.01), t_{(266.27)}=$ 4.43, $p<.001$, Cohen's $d=.54$ ). Males also consistently reported higher prevalence in most types of delinquency than females (all $p$ 's $<.001$, effect size ranging from .44 to .70) except drug offense and property offense, in which both male and female respondents reported similar levels of delinquency $(p>$ $.05)$. Multiple regression analysis of total delinquency on age and gender showed that older and male adolescents (young male adults) tend to have higher delinquency than younger and female adolescents $(\beta=$ .38 and -.24 for age and gender respectively, $R^{2}=.16$ ). These findings concur with existing research literature (e.g. Stams et al. 2006).

Pearson's correlation analysis and linear regression analysis were conducted to assess the association between delinquency and the three independent variables (moral reasoning, moral self, self-esteem). Delinquency was negatively correlated with moral reasoning $(r=-.19, p<.01)$ and moral self-concept $(r=$ $-.15, p<.05)$, but not significantly correlated with general self-esteem $(r=.005, p>.05)$ (Table 3). Linear regression analysis revealed similar results even after controlling the effect of age and gender. Delinquency was found to regress on moral self $(\beta=-.26, p=.001)$ and moral reasoning ( $\beta=-.18, p=.006)$, but not significantly on general self-esteem $(\beta=.14, p>.05)$. Furthermore, self-esteem was not correlated with any kind of delinquency, whereas moral self-concept and 
Table 2: Descriptive Statistics of Delinquent Behavior Across Male and Female Respondents

\begin{tabular}{|c|c|c|c|c|}
\hline Dependent Variable & $\begin{array}{c}\text { Male } \\
\text { M (SD) }\end{array}$ & $\begin{array}{l}\text { Female } \\
\mathrm{M}(S D)\end{array}$ & t-test & $\begin{array}{l}\text { Effect Size } \\
\text { (Cohen's } d)\end{array}$ \\
\hline Self-esteem & $13.90(5.22)$ & $14.98(4.80)$ & $-1.72 n s$ & -.22 \\
\hline Moral Self & $12.54(4.57)$ & $14.87(3.70)$ & $-4.56^{\star *}$ & -.56 \\
\hline Moral Reasoning & $6.06(1.33)$ & $5.99(1.13)$ & $.42 n s$ & .057 \\
\hline Total delinquency & $47.37(20.63)$ & 38.01 (13.28) & $4.43^{\star *}$ & .54 \\
\hline Gambling & $1.69(1.04)$ & $1.26(.51)$ & $4.51^{* *}$ & .52 \\
\hline Violence offence & $1.49(.67)$ & $1.23(.44)$ & $3.92^{\star \star}$ & .46 \\
\hline Property offence & $1.17(.44)$ & $1.09(.39)$ & $1.51 n s$ & .19 \\
\hline Gangsters & $1.74(1.03)$ & $1.36(.66)$ & $3.69^{* \star}$ & .44 \\
\hline Sexual misconduct & $2.14(1.22)$ & $1.43(.76)$ & $5.79^{* *}$ & .70 \\
\hline Drug offence & $1.25(.75)$ & $1.16(.59)$ & $1.19 n s$ & .13 \\
\hline
\end{tabular}

${ }^{*} p<.05,{ }^{* *} p<.01, n s=$ non-significant.

Table 3: Pearson's Correlations between Delinquency and Self-Esteem, Moral Self-Concept, Moral Reasoning

\begin{tabular}{|c|c|c|c|}
\hline & self-esteem & moral self & moral reasoning \\
\hline \hline delinquency (total) & $.005 n s$ & $-.153^{*}$ & $-.186^{* *}$ \\
\hline gambling & $.052 n s$ & $-.13^{*}$ & $-.136^{*}$ \\
\hline violence offence & $.068 n s$ & $-.053 n s$ & $-.051 n s$ \\
\hline property offence & $.040 n s$ & $-.01 n s$ & $-.248^{* *}$ \\
\hline gangsters & $-.005 n s$ & $-.177^{* *}$ & $-.102 n s$ \\
\hline sexual misconduct & $.009 n s$ & $-.167^{* *}$ & $-.19^{* *}$ \\
\hline drug offence & $-.062 n s$ & $-.084 n s$ & $-.136^{*}$ \\
\hline
\end{tabular}

${ }^{*} p<.05,{ }^{* *} p<.01, n s=$ non-significant.

moral reasoning did correlate with various kinds of delinquency though not in a uniform pattern. Gambling and sexual misconduct were correlated negatively with both moral reasoning and moral self. Delinquency associated with gangsters was correlated with moral self but not with moral reasoning, whereas drug offense and property offense were correlated with moral reasoning but not with moral self. Violence offense was not correlated with either moral reasoning or moral self. Self-esteem, as a global measure of self-concept, was not correlated with any kind of delinquency (all $p$ 's > $.05)$, indicating that either there was no simple linear relationship between global self-esteem and delinquency or, if there was any kind of relationship, their relationship could be a non-linear one.

While linear relationship between self-esteem and delinquency was not found, one could not preclude that some non-linear relationship might exist between selfesteem and delinquency. In order to check if selfesteem had non-linear relation with delinquency, the method of analysis of variance using polynomial contrasts tests was applied, in which self-esteem was divided into three equal intervals for the independent variable (i.e. cutoffs at every one-third of the GS total score), whereas total delinquency and different kinds of delinquency were entered as dependent variables. Results of the polynomial contrasts tests were shown in Table 4. As a result, overall F-test was significant in total delinquency $\left(F_{(2,254)}=3.89, p<.05, \eta^{2}=.03\right)$ and three kinds of delinquency, namely, sexual misconduct, drug offense, gambling $\left(F_{(2,260}\right.$ to 261) $=7.53,6.58$, $3.08, \eta^{2}=.02$ to .06 respectively), whereas gangsters, violence, and property thefts did not show significant differences with self-esteem levels. Furthermore, polynomial contrast tests suggested that all of the significant differences were following a curvilinear (i.e. U-shape) rather than a linear trend. Delinquent acts associated with sexual misconduct, drugs, and gambling were at higher levels when self-esteem was at its lowest. Delinquency dropped to lowest level when self-esteem was on the medium level, but an inverted 
Table 4: Descriptive Statistics and Polynomial Contrast Tests of Self-Esteem, Moral Self, and Moral Reasoning on Delinquent Behavior

\begin{tabular}{|c|c|c|c|c|c|c|c|c|}
\hline & & \multicolumn{3}{|c|}{$\mathrm{M}(S D)$} & \multirow{2}{*}{$\begin{array}{l}\text { Overall } \\
\text { F-test }\end{array}$} & \multirow{2}{*}{$\begin{array}{c}\text { Effect Size } \\
\left(\eta^{2}\right)\end{array}$} & \multicolumn{2}{|c|}{ Polynomial Contrasts } \\
\hline & & Low & Mid & High & & & linear & quadratic \\
\hline $\begin{array}{c}\text { Total } \\
\text { delinquency }\end{array}$ & $\begin{array}{c}\text { self-esteem } \\
\text { moral self } \\
\text { moral reasoning }\end{array}$ & $\begin{array}{l}48.92(19.36) \\
55.10(20.92) \\
54.11(23.06)\end{array}$ & $\begin{array}{l}40.55(13.93) \\
41.88(15.37) \\
44.17(18.37)\end{array}$ & $\begin{array}{l}45.59(22.87) \\
42.37(23.08) \\
41.18(17.50)\end{array}$ & $\begin{array}{l}3.89^{*} \\
6.77^{* *} \\
5.21^{\star *}\end{array}$ & $\begin{array}{l}.03 \\
.05 \\
.04\end{array}$ & $\begin{array}{c}.87 n s \\
9.70^{\star *} \\
10.41^{\star *}\end{array}$ & $\begin{array}{c}7.78^{* *} \\
7.68^{\star} \\
1.72 n s\end{array}$ \\
\hline Gambling & $\begin{array}{c}\text { self-esteem } \\
\text { moral self } \\
\text { moral reasoning }\end{array}$ & $\begin{array}{l}1.68(1.03) \\
2.01(1.22) \\
1.84(1.03)\end{array}$ & $\begin{array}{l}1.38(.66) \\
1.47(.81) \\
1.55(.92)\end{array}$ & $\begin{array}{l}1.63(1.06) \\
1.40(.82) \\
1.43(.81)\end{array}$ & $\begin{array}{l}3.08^{*} \\
5.55^{\star *} \\
2.36 n s\end{array}$ & $\begin{array}{l}.02 \\
.04 \\
.02\end{array}$ & $\begin{array}{l}.06 n s \\
9.81^{\star *} \\
4.64^{*}\end{array}$ & $\begin{array}{l}5.83^{*} \\
4.17^{\star} \\
.43 n s\end{array}$ \\
\hline $\begin{array}{l}\text { Violence } \\
\text { offence }\end{array}$ & $\begin{array}{c}\text { self-esteem } \\
\text { moral self } \\
\text { moral reasoning }\end{array}$ & $\begin{array}{l}1.44(.61) \\
1.53(.66) \\
1.52(.80)\end{array}$ & $\begin{array}{l}1.32(.42) \\
1.35(.48) \\
1.39(.59)\end{array}$ & $\begin{array}{l}1.45(.78) \\
1.41(.82) \\
1.37(.58)\end{array}$ & $\begin{array}{l}1.51 n s \\
1.20 n s \\
.60 n s\end{array}$ & $\begin{array}{l}.01 \\
.01 \\
.01\end{array}$ & $\begin{array}{l}.00 n s \\
.77 n s \\
1.17 n s\end{array}$ & $\begin{array}{l}2.66 n s \\
2.21 n s \\
.40 n s\end{array}$ \\
\hline $\begin{array}{l}\text { Property } \\
\text { offence }\end{array}$ & $\begin{array}{c}\text { self-esteem } \\
\text { moral self } \\
\text { moral reasoning }\end{array}$ & $\begin{array}{l}1.22(.46) \\
1.26(.52) \\
1.44(.79)\end{array}$ & $\begin{array}{l}1.09(.25) \\
1.10(.27) \\
1.13(.41)\end{array}$ & $\begin{array}{l}1.17(.57) \\
1.17(.64) \\
1.07(.26)\end{array}$ & $\begin{array}{l}2.05 n s \\
2.12 n s \\
8.08^{\star *}\end{array}$ & $\begin{array}{l}.02 \\
.02 \\
.06\end{array}$ & $\begin{array}{l}.39 n s \\
.79 n s \\
15.94^{\star *}\end{array}$ & $\begin{array}{l}4.10^{*} \\
4.16^{\star} \\
4.36^{\star}\end{array}$ \\
\hline Gangsters & $\begin{array}{c}\text { self-esteem } \\
\text { moral self } \\
\text { moral reasoning }\end{array}$ & $\begin{array}{c}1.73(.84) \\
2.22(1.14) \\
2.00(1.18)\end{array}$ & $\begin{array}{l}1.53(.88) \\
1.50(.81) \\
1.58(.84)\end{array}$ & $\begin{array}{l}1.61(.98) \\
1.52(.95) \\
1.56(.95)\end{array}$ & $\begin{array}{l}.71 n s \\
8.52^{\star *} \\
2.68 n s\end{array}$ & $\begin{array}{l}.01 \\
.06 \\
.02\end{array}$ & $\begin{array}{c}.48 n s \\
12.45^{\star \star} \\
4.92^{*}\end{array}$ & $\begin{array}{l}1.30 n s \\
9.73^{* *} \\
2.31 n s\end{array}$ \\
\hline $\begin{array}{c}\text { Sexual } \\
\text { misconduct }\end{array}$ & $\begin{array}{c}\text { self-esteem } \\
\text { moral self } \\
\text { moral reasoning }\end{array}$ & $\begin{array}{l}2.20(1.15) \\
2.64(1.41) \\
2.61(1.16)\end{array}$ & $\begin{array}{l}1.59(.93) \\
1.76(1.00) \\
1.83(1.07)\end{array}$ & $\begin{array}{l}2.07(1.25) \\
1.70(1.11) \\
1.74(1.10)\end{array}$ & $\begin{array}{l}7.53^{\star *} \\
8.98^{\star \star} \\
7.14^{\star *}\end{array}$ & $\begin{array}{l}.06 \\
.06 \\
.06\end{array}$ & $\begin{array}{l}.43 n s \\
14.92^{* \star} \\
13.69^{* *}\end{array}$ & $\begin{array}{l}14.69^{\star *} \\
7.95^{\star *} \\
5.01^{\star}\end{array}$ \\
\hline Drug offence & $\begin{array}{c}\text { self-esteem } \\
\text { moral self } \\
\text { moral reasoning }\end{array}$ & $\begin{array}{l}1.55(.97) \\
1.50(1.04) \\
1.55(1.09)\end{array}$ & $\begin{array}{l}1.10(.43) \\
1.15(.53) \\
1.18(.64)\end{array}$ & $\begin{array}{l}1.24(.81) \\
1.25(.83) \\
1.18(.62)\end{array}$ & $\begin{array}{l}6.58^{\star *} \\
3.45^{\star} \\
3.55^{\star}\end{array}$ & $\begin{array}{l}.05 \\
.03 \\
.03\end{array}$ & $\begin{array}{c}5.92^{*} \\
2.61 n s \\
6.26^{*}\end{array}$ & $\begin{array}{l}11.09^{* *} \\
6.08^{*} \\
3.52 n s\end{array}$ \\
\hline
\end{tabular}

${ }^{*} p<.05,{ }^{* *} p<.01, n s=$ non-significant

relationship occurred showing that self-esteem was regaining higher levels with increasing delinquency (see Figure 1).

In order to check whether moral reasoning and moral self-concept had a linear or quadratic relation with delinquency, similar analyses were conducted on moral reasoning and moral self (Table 4). Unlike selfesteem, moral reasoning exhibited a linear negative trend with total delinquency and with most delinquent behaviors (except violence offense) (Figure 2).
Respondents scored more highly on the moral reasoning test tended to engage less delinquent behaviors except violence offense. Moral self exhibited similar pattern of association (i.e. linear trend) with delinquency though mixed with some curvilinear trends as self-esteem did. Nevertheless, moral self showed a more extensive effects on various kinds of delinquent behaviors than global self-esteem did. It was found that moral self was predictive of all kinds of delinquent behaviors except violence and property offense.

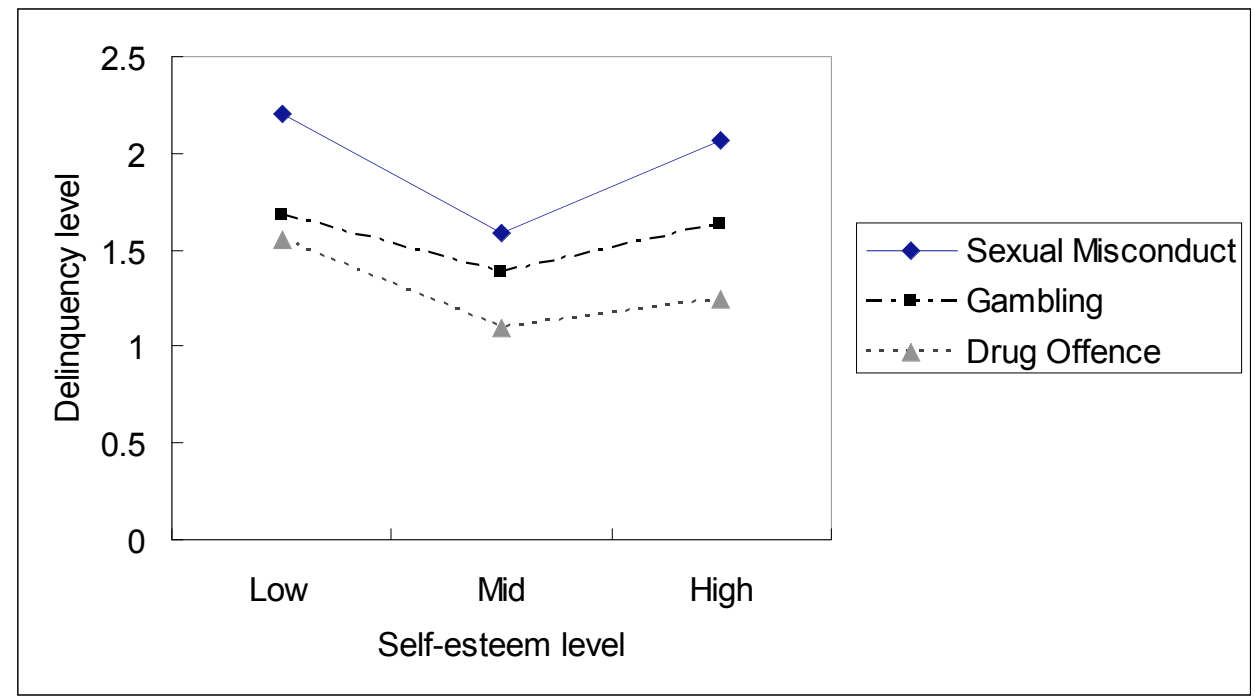

Figure 1: Self-esteem by Sexual Misconduct, Gambling, Drug offenses. 


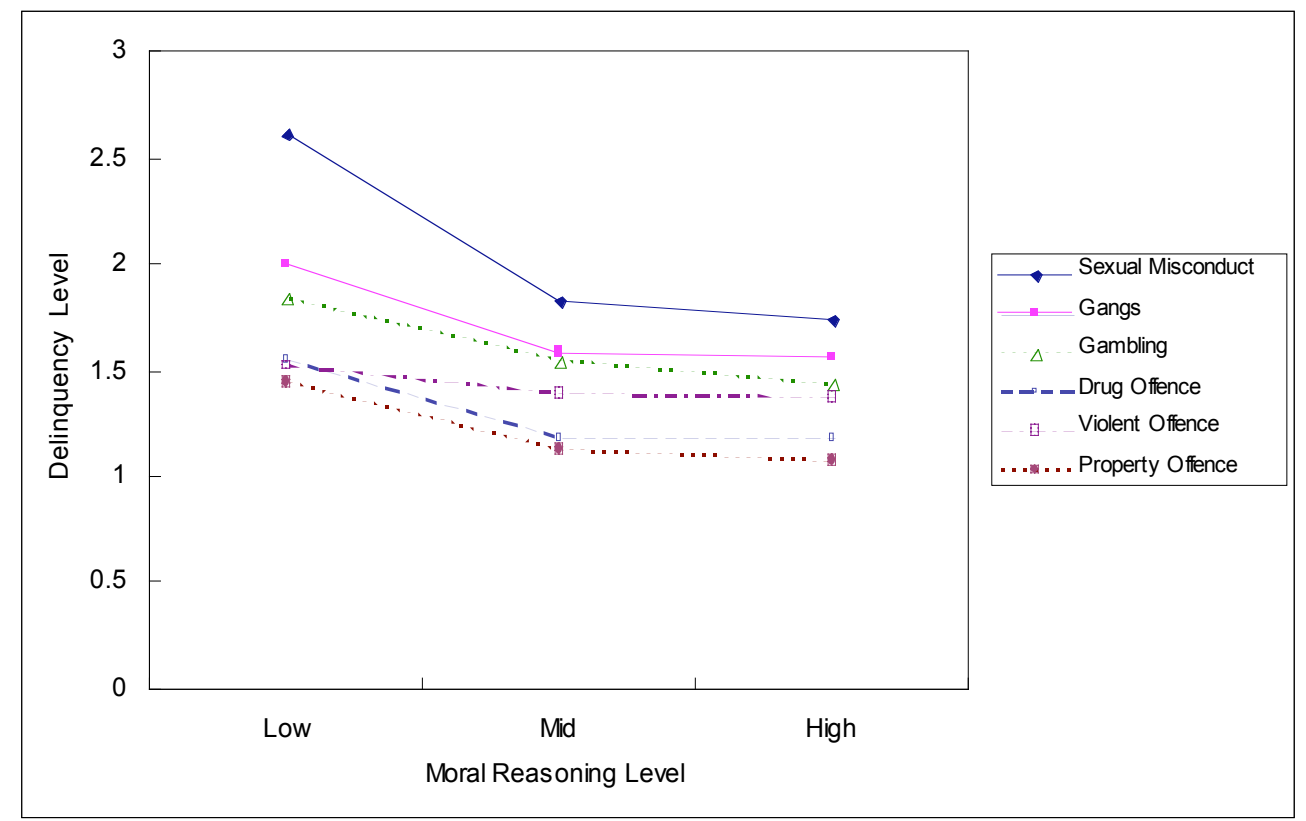

Figure 2: Moral Reasoning by Delinquent Behaviors.

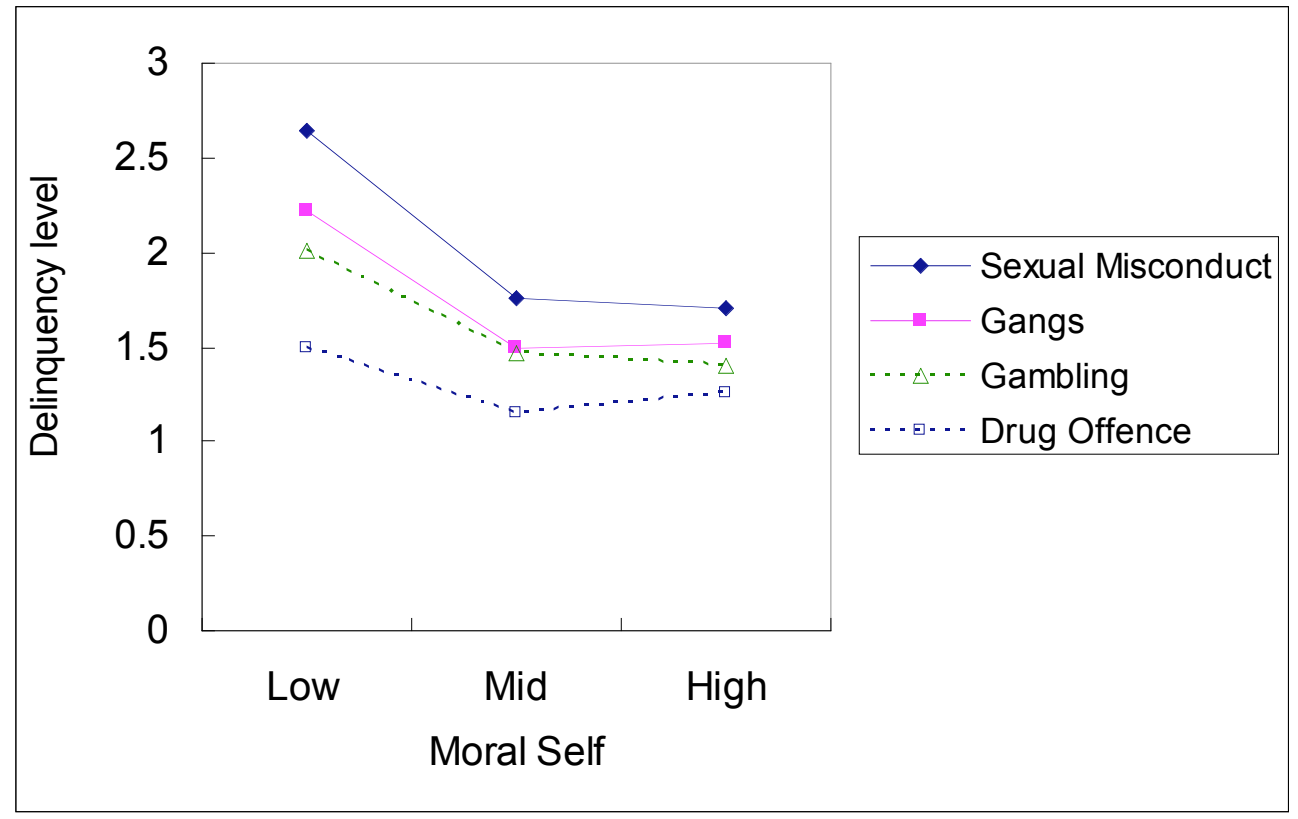

Figure 3: Moral Self by Delinquent Behaviors.

To summarize, moral reasoning and moral self are in general negatively associated with delinquency. Young people engaged more frequently in various kinds of delinquent behaviors had lower moral reasoning ability or moral maturity and lower moral self. However, moral reasoning and moral self were not predictive of violence offense.

\section{DISCUSSION}

Our research has confirmed and added to the existing body of empirical evidence regarding the internal factors associated with delinquency. As reported in other studies (e.g. Donker et al. 2003; Mullis et al. 2004), male and older Chinese adolescents (early adults) in Hong Kong also had higher prevalence in self-report delinquency than female and younger respondents, effect size of this gender effect was quite high (Cohen's $d=.54$ ). While males and females did not differ in moral reasoning ability or in their global self-esteem, females held higher views of their moral self than the male respondents did. These demographic characteristics of delinquency were 
similar to those reported elsewhere (e.g. Johnston \& Krettenauer 2011; Raaijmakers et al. 2005; Stams et al. 2006).

Regarding the correlates of delinquency, we have found pervasive evidence supporting that moral reasoning is predictive of delinquent behaviors. Respondents who scored more highly on the moral reasoning test showed less delinquent behaviors in general and in various types of delinquent behaviors (except violence offense). This finding implied that most delinquent behaviors were associated with one's moral reasoning maturity. It was however noteworthy that both violence offense and property offense did not have significant effect with moral self-concept, which was found to be predictive of most types of delinquency. Further studies on violence and property offenses may look into other correlates of delinquency such as personality traits of aggressiveness, psychoticism or extraversion, which other studies have suggested to be responsible for antisocial behavior (e.g Aleixo and Norris 2000; Wyatt and Carlo 2002).

Our findings suggest that moral self, being the most pertinent aspect of self cognition in delinquency, was more predictive of delinquency than did the global self, which being measured as a global trait might exhibit a less salient association with delinquency. It was noted that moral self (i.e. self evaluative views in the moral domain) did exhibit a negative association with delinquency in a more extensive way than global selfesteem did, such that it was predictive of all most delinquent behaviors except violence offense. Moral self also showed a higher effect size than moral reasoning in explaining the variance of delinquent behaviors except violence and property offense. This finding was congruent with other research studies (e.g. Johnston and Krettenauer 2011; Tarry and Emler 2007) which suggested that moral self and moral values were more predictive of delinquency.

To date, research has generated inconclusive findings regarding high self-esteem as inoculants against negative outcomes (e.g. Donnellan et al. 2005; Kaplan et al. 1986; Owens 1994; Jang \& Thornberry 1998). Our finding that self-esteem (and to certain extent moral self) exhibited a curvilinear relation ( $U$ shape trend) with delinquency could offer to explain this apparently inconsistent conclusion. Similar curvilinear relationship was observed in other research (e.g. Lo et al. 2011). This phenomenon may explain why very low or even non-significant correlation between self-esteem and delinquency was reported in some studies. It could be due to the fact that the curvilinear relation can hardly be denoted by methods of linear correlation, regression or mediating analysis (see Shavelson 1996).

Nevertheless, the fact that both high and low selfesteem people have reported highest levels of delinquency does echo with some postulations of both the self-derogation theory (Kaplan 1980) and the notion of "threatened ego" (Baumeister, Smart \& Boden 1996). The curvilinear nature of the relation between self-esteem and delinquency was not entirely contradictory to the self-derogation theory, although when Kaplan (1978) first proposed the theory he only contended that low self-esteem was conducive of delinquent behavior. In the process of re-establishing the impaired esteem, adolescents would tend to reject the conventional social groups and turned to other new groups such as delinquent associates which granted them approval. Hence, lowered self-esteem predisposes a person toward delinquency, but after an extended period of engaging in delinquency the delinquent youths will rebuild their self-esteem. This self-enhancing effect of frequent delinquency may be more manifested in one's self-concept in the social and physical domains. Under a multidimensional model of self-concept, Leung and Lau (1989) reported that the enactment of delinquent behaviors would enhance one's social and physical self-concept, whereas rejection by school and family would push the children to seek approval from other referent groups (such as delinquent peers).

The correlation between high self-esteem and delinquency may reflect another perspective narcissism and the notion of "threatened ego". Challenging the popular view that low self-esteem was conducive of delinquency, Baumeister, Smart and Boden (1996) introduced the concept of threatened egotism. They contended that aggressive behavior was the result of one's feeling of superiority being undermined or threatened. In particular, a grandiose sense of self, i.e. narcissism, should be the most prone to aggressive acts when challenged (Ang \& Yusof, 2005; Barry, Grafeman, Adler \& Pickard, 2007; Bushman \& Baumeister, 1998; Bushman, Baumeister, Thomaes, Ryu, Begeer \& West, 2009). Hence, we could expect that low self-esteem is conducive of delinquent behavior in the beginning, but delinquency can also be expected to have a self-serving effect in rebuilding a global sense of self-worth over time, though this sense of self-worthiness may be distorted and exaggerated, and could be confounded with the 
narcissistic self. Under this interactive process of the self cognitions and delinquent behavior, it is logical to find high delinquents reporting a high global self (but low moral self and moral reasoning). In this regard, the moral self-concept should be a better (or more valid) predictor of delinquency than the global self-esteem.

Another issue needs to be discussed is the dimensionality of the self construct. Most previous research on delinquency and self-esteem has assumed a global trait of self-worthiness (self-esteem) and neglected the multidimensional nature of self-concept (Shavelson, Hubner, and Stanton 1976). To account for the low or even non-significant statistical correlations between self-concept and deviance, researchers questioned the operational definition of self-esteem by a global (or unidimensional) factor in measurement. Wells and Rankin (1983) pointed out that global selfesteem was only one aspect of the full picture of selfconcept which has been shown to be multifaceted in nature (Shavelson et al. 1976). The relatively weak association between low self-esteem and delinquency found in Mason's (2001) study also suggested that global self-esteem might not be able to serve as a strong and precise predictor when compared with other specific components of self-esteem. Empirically, studies adopting a multidimensional model of selfconcept instead of a global self-esteem measure have rendered more promising results (e.g. Carroll et al. 2007; Hay 2000; Leung and Lau 1989; Mason, 2001; Owens, 1994). For example, Leung and Lau (1989) have showed that a multidimensional self-concept model could better reveal the intricate relations between self-esteem and delinquency. While specific facets of self-concept showed different patterns of relation with delinquency, the global self-concept in their study did not show any significant relation with delinquency. Similarly, our study also found that moral self was more predictive of delinquent behavior than global self-esteem did. To conclude, our study has provided further support arguing for the need to take a multidimensional approach in assessing self-concept (e.g. Carroll et al. 2007; Leung \& Lau 1989) as well as in analyzing the relation between moral reasoning and delinquency (e.g. Raaijmakers, Engels, \& Van Hoof 2005).

\section{LIMITATIONS AND SUGGESTIONS}

Due to practical constraints this study took a crosssectional instead of longitudinal approach. A longitudinal design should provide stronger evidence in explaining the reciprocal effects between the self variables (self-esteem, moral self, moral reasoning) and delinquent behavior. Given the curvilinear nature of the effects of self-esteem and moral self on delinquency detected in this study, future research may look into the process structure between these variables under a longitudinal framework. Another limitation was the sampling method. Although the samples drawn did possess sufficient variation both in terms of demographics and the variables concerned (say, types of delinquent behaviors), our sampling method did not guarantee high representativeness of the community. If feasible, a proportional stratified sampling should enhance the representativeness of the study. Another issue that awaits further investigation is the effects of the multidimensional self on different kinds of delinquent behaviors. Though this study suggested that moral self was more predictive than global self in explaining delinquent behaviors, other dimensions of self-concept (e.g. family, academic, physical, social) were not included. Further studies may adopt a more comprehensive model of the self in their investigation of the effects of self-concept on different kinds of delinquent behaviors. Lastly, the measurement of moral reasoning maturity employed in this study was based on a Taiwanese version (Jou 2004) of a moral reasoning test similar to the DIT (Rest 1986), but the test-retest reliability and validity of this instrument for the Chinese samples in Hong Kong or other Chinese communities was unknown. Though the pattern of correlation of this test with Moral Self and General Self scales did provide us some confidence in its construct validity, more psychometric information of the test should be helpful in interpreting the test scores. To conclude, the findings that moral self and moral reasoning are more predictive of delinquency than global self-esteem offer important implications to the human service professionals (such as teachers, social workers, counselors) in Hong Kong or other similar communities. As a protective factor against delinquency, bolstering individuals' self-esteem may not be as effective as sensitizing young people's moral self and nurturing their moral reasoning ability. The predictive effects of moral self and moral reasoning also echo well with the salience of moral values in the Chinese societies and Chinese self-conceptions (Bond 1997; Cheng 1996).

\section{REFERENCES}

Aleixo, P. A., \& Norris, C. E. 2000. "Personality and Moral Reasoning in Young Offenders." Personality and Individual Differences, 28(3):609-623. http://dx.doi.org/10.1016/S0191-8869(99)00124-5 
Aloise-Young, P. A., Hennigan, K. M., Leong, C. W. 2001. "Possible Sevles and Negative Health Behaviors During Early Adolescence." The Journal of Early Adolescence, 21(2):158181.

http://dx.doi.org/10.1177/0272431601021002002

Ang, R., \& Yusof, N. 2005. "The Relationship between Aggression, Narcissism, and Self-esteem in Asian Children and Adolescents." Current Psychology, 24(2):113-122. http://dx.doi.org/10.1007/s12144-005-1010-0

Apple Daily. 2013. "School Girl Worked as Sex Partner to Earn Tuition Fees." Apple Daily. Retrieved April 19, 2013, http://hk.apple.nextmedia.com/news/art/20130419/18233264

Aunola, K., Stattin, H., \& Nurmi, J. 2000. "Adolescents' Achievement Strategies, School Adjustment, and Externalizing and Internalizing Problem Behaviors." Journal of Youth and Adolescence, 29(3):289-306. http://dx.doi.org/10.1023/A:1005143607919

Baldry, A. C., \& Farrington, D. P. 2000. "Bullies and Delinquents: Personal Characteristics and Parental Styles." Journal of Community and Applied Social Psychology, 10(1):17-31. http://dx.doi.org/10.1002/(SICI)10991298(200001/02)10:1<17::AID-CASP526>3.0.CO;2-M

Barry, C., Grafeman, S., Adler, K. \& Pickard, J. 2007. "The Relations among Narcissism, Self-esteem, and Delinquency in a Sample of At-risk Adolescents." Journal of Adolescence, 30(6): $933-942$. http://dx.doi.org/10.1016/j.adolescence.2006.12.003

Baumeister, R.F., Smart, L., \& Boden, J.M. 1996. "Relation of Threatened Egotism to Violence and Aggression: The Dark Side of High Self-esteem." Psychological Review, 103(1):533 http://dx.doi.org/10.1037/0033-295X.103.1.5

Beerthuizen, Marinus G. C., Brugman, D., and Basinger, K. S. 2013. "Oppositional Defiance, Moral Reasoning and Moral Value Evaluation as Predictors of Self-reported Juvenile Delinquency." Journal of Moral Education, 42(4):460-474 http://dx.doi.org/10.1080/03057240.2013.803955

Bond, M. H. 1997. "Values and Moral Behavior in Mainland China." Psychologia, 40(4): 251-264.

Broadhurst, R. G. 2004. "Crime Trends in Hong Kong: Another Look at the Safe City." Pp. 133-149 in Crime and its Control in PR China: Proceedings of the Annual Symposium 2000-2002, edited by Broadhurst, Roderic G. Hong Kong: Centre for Criminology, University of Hong Kong. Retrieved from Apr 1, 2014 http://eprints.qut.edu.au/5386/1/5386_1.pdf

Broadhurst, R., Lee, K. W., Chan, C. Y. 2013. "Crime Trends." Pp. 45-68 in Understanding Criminal Justice in Hong Kong, edited by Chui, W. H., and Lo, T. W. Hong Kong: Willan Publishing.

Brownfield, D., \& Thompson, K. 2005. "Self-concept and Delinquency: The Effects of Reflected Appraisals by Parent and Peers." Western Criminology Review, 6(1):22-29.

Bushman, B., \& Baumeister, R. 1998. "Threatened Egotism, Narcissism, Self-esteem, and Direct and Displaced Aggression: Does Self-love or Self-hate Lead to Violence?" Journal of Personality and Social Psychology, 75(1):219 229.

http://dx.doi.org/10.1037/0022-3514.75.1.219

Bushman, B., Baumeister, R., Thomaes, S., Ryu, E., Begeer, S., \& West, S. 2009. "Looking Again, and Harder, for a Link between Low Self-esteem and Aggression." Journal of Personality, 77(2):427 - 446 . http://dx.doi.org/10.1111/j.1467-6494.2008.00553.x

Carroll, A., Houghton, S., Wood, R., Perkins, C., \& Bower, J. 2007. "Multidimensional Self-concept Age and Gender Differences in Australian High School Students Involved in Delinquent Activities." School Psychology International, 28(2):237-256. http://dx.doi.org/10.1177/0143034307078106
Chen, C.A., \& Howitt, D. 2007. "Different Crime Types and Moral Reasoning Development in Young Offenders Compared with Non-offender Controls." Psychology, Crime and Law, 13(4):405-416

http://dx.doi.org/10.1080/10683160601060788

Cheng, C.H.K. 1996. "Towards a culturally relevant model of selfconcept for the Hong Kong Chinese." Pp. 235-254 in Asian Contributions to Cross-Culturally Psychology, edited by Pandey J., Sinha D., and D.P.S. Bhawuk D. P. S. London: Sage Publications.

Cheng, C.H.K., \& Watkins, D. 2000. "Age and Gender Invariance of Self-concept Factor Structure: An Investigation of a Newly Developed Chinese Self-concept Instrument." International Journal of Psychology, 35(5):186-193. http://dx.doi.org/10.1080/00207590050171120

Cheung, Y. W. 1997. "Family, School, Peer, and Media Predictors of Adolescent Deviant Behavior in Hong Kong." Journal of Youth and Adolescence, 26(5):569 - 596. http://dx.doi.org/10.1023/A:1024534022895

Cheung, C. K., Ngai, N. P., and Ngai, S. Y. 2006. "Family Strain and Adolescent Delinquency in Two Chinese Cities, Guangzhou and Hong Kong." Journal of Child and Family Studies, 16(5):626-641.

http://dx.doi.org/10.1007/s10826-006-9112-3

Chui, W. H., Chan, H. C. 2011. "Criminal Recidivism among Hong Kong Male Juvenile Probationers." Journal of Child and Family Studies, 21(5):857-868. http://dx.doi.org/10.1007/s10826-011-9546-0

Davis, C., Tang, C., \& Ko, J. 2002. "Assessing the Impact of Socia Factors on the Mental Health of Chinese at Risk Adolescents in Hong Kong." British Journal of Social Work, 32(5):609-619. http://dx.doi.org/10.1093/bjsw/32.5.609

Davis, C., Tang, C., \& Ko, J. 2004. "Impact of Peer, Family and School on Delinquency: A Study of At-risk Chinese Adolescents in Hong Kong." International Social Work, 47(4):489-502. http://dx.doi.org/10.1177/0020872804046255

Donker, A. G., Smeenk, W. H., van der Laan, P. H., \& Verhulst, F. C. 2003. "Individual Stability of Antisocial Behavior from Childhood to Adulthood: Testing the Stability Postulate of Moffit's Developmental Theory." Criminology, 41(3):593-609. http://dx.doi.org/10.1111/j.1745-9125.2003.tb00998.x

Donnellan, B. Trzensniewski, K., Robins, R., Moffitt, T., \& Caspi, A 2005. "Low Self-esteem Is Related To Aggression, Antisocial Behavior, and Delinquency." Psychological Science, 16(4):328-335. http://dx.doi.org/10.1111/j.0956-7976.2005.01535.x

EMB. 2003. Users' and Training Manual for Measuring Secondary Students' Performance in Affective and Social Domains. Hong Kong: The Education and Manpower Bureau, the Government of the Hong Kong SAR.

Gebhard, H. \& Bernard, P. 2007. "Social Integration of adolescents at risk: Results from a cohort study." Vulnerable Children and Youth Studies, 2(3):215-226. http://dx.doi.org/10.1080/17450120701459922

Hammond, T. \& Nicholas, E. 2007. "Attitude, Values and Moral Reasoning as predictors of Delinquency." British Journal of Developmental Psychology, 25(2):169-183. http://dx.doi.org/10.1348/026151006X113671

Hay, I. 2000. "Gender Self-concept Profiles of Adolescents Suspended from High School." Journal of Child Psychology and Psychiatry, 41(3):345-352. http://dx.doi.org/10.1111/1469-7610.00618

HKSAR, 2013. "Hong Kong Annual Digest of Statistics 2004-2013. Hong Kong: Census and Statistics Department, Hong Kong SAR Government. Retrieved Mar 31, 2014 http://www.censtatd.gov.hk/hkstat/sub/sp140.jsp?productCod e=B1010003 
Huey, S.J., Henggeler, S.W., Brondino, M.J., \& Pickrel, S.G. 2000. "Mechanisms of Change in Multisystemic Therapy: Reducing Delinquent Behavior through Therapist Adherence and Improved Family and Peer Functioning." Journal of Consulting and Clinical Psychology, 68(3):451-467. http://dx.doi.org/10.1037/0022-006X.68.3.451

Iselin, A. R., DeCoster, J., \& Salekin, R. T. 2009. "Maturity in adolescent and young adult offenders: The role of cognitive control." Law and Human Behavior, 33(6): 455-469. http://dx.doi.org/10.1007/s10979-008-9160-x

Jang, S.J., \& Thornberry, T.P. 1998. "Self-esteem, Delinquent Peers, and Delinquency: A Test of the Self-enhancement Thesis." American Sociological Review, 63:586-598. http://dx.doi.org/10.2307/2657269

Johnston, M., \& Krettenauer, T. 2011. "Moral Self and Moral Emotion Expectancies as Predictors of Anti-and Prosocial Behaviour in Adolescence: A case for Mediation?" European Journal of developmental psychology, 8(2):228-243.

http://dx.doi.org/10.1080/17405621003619945

Jou, S.H. 2004. Juvenile Delinquency. Taiwan: Wu Nan Publishing.

Kaplan, H. 1978. "Deviant Behavior and Self-enhancement in Adolescence." Journal of Youth and Adolescence, 7(3):253273. http://dx.doi.org/10.1007/BF01537977

Kaplan, H.B. 1980. Deviant Behaviour in Defense of Self. New York: Academic Press.

Kaplan, H. B., Johnson, R. J., \& Bailey, C. A. 1986. "Self-rejection and the Explanation of Deviance: Refinement and Elaboration of a Latent Structure." Social Psychology Quarterly, 49(2):101-128. http://dx.doi.org/10.2307/2786723

Kohlberg, L. 1969. Stage and Sequence: The Cognitivedevelopmental Approach to Socialization. In D.A. Goslin (Ed.), Handbook of socialization theory and research. Chicago: Rand McNally.

Lau, S., \& Leung, K. 1992. "Relations with Parents and School and Chinese Adolescents' Self-concept, Delinquency, and Academic Performance." British Journal of Educational Psychology, 62(2):193-202.

http://dx.doi.org/10.1111/j.2044-8279.1992.tb01013.x

Leung, K., \& Lau, S. 1989. "Effects of Self-concept and Perceived Disapproval of Delinquent Behavior in School Children." Journal of Youth and Adolescence, 18(4):345-359. http://dx.doi.org/10.1007/BF02139254

Lo, T.W., Cheng, C.H.K., Wong, D.S.W., Rochelle, T.L., and Kwok, S.I. 2011. "Self-esteem, Self-efficacy and Deviant Behavior of Young People in Hong Kong." Advances in Applied Sociology, 1:48-55.

http://dx.doi.org/10.4236/aasoci.2011.11004

Ma, H. K., Shek, T. L., and Lam, O. B. 2000. "Parental, Peer, and Teacher Influences on the Social Behavior of Hong Kong Chinese Adolescents." The Journal of Genetic Psychology, 161(1): 65-78.

http://dx.doi.org/10.1080/00221320009596695

Mason, A. 2001. "Self-esteem and Delinquency Revisited (Again): A Test of Kaplan's Self-derogation Theory of Delinquency Using Latent Growth Curve Modeling." Journal of Youth and Adolescents, 30(1):83-102. http://dx.doi.org/10.1023/A:1005276905961

Mullis, R. L., Cornille, T. A., Mullis, A. K., \& Huber, J. 2004. "Female Juvenile Offending: A Review of Characteristics and Contexts." Journal of Child and Family Studies, 13(2):205218. http://dx.doi.org/10.1023/B:JCFS.0000015708.71295.2a

Nelson, J.R., Smith, D. J., \& Dodd, J. 1990. "The Moral Reasoning of Juvenile Delinquents: A Meta-analysis." Journal of Abnormal Child Psychology, 18(3):231-239.

http://dx.doi.org/10.1007/BF00916562
Ngai, N. P., and Cheung, C. K. 2005. "Predictors of the Likelihood of Delinquency: A Study of Marginal Youth in Hong Kong, China." Youth \& Society, 36:445-470. http://dx.doi.org/10.1177/0044118X04265090

Overbeek, G., Vollebergh, W., Engels, R., \& Meeus, W. 2005 "Juvenile delinquency as acting out: Emotional disturbance mediating the effects of parental attachment and life events." European Journal of Developmental Psychology, 2(1):39-46. http://dx.doi.org/10.1080/17405620444000184

Owens, T.J. 1994. "Two Dimensions of Self-esteem: Reciprocal Effects of Positive Self-worth and Self-deprecation on Adolescent Problems." American Sociological Review, 59(3):391-407. http://dx.doi.org/10.2307/2095940

Piaget, J. 1965. The Moral Judgement of the Child. IL: The Free Press.

Raaijmakers, Q. A., Engels, R. C., \& Van Hoof, A. 2005 "Delinquency and Moral Reasoning in Adolescence and Young Adulthood." International Journal of Behavioral Development, 29(3):247-258 http://dx.doi.org/10.1177/01650250544000035

Rest, J. R. 1975. "Longitudinal Study of the Defining Issues Test of Moral Judgment: A Strategy for Analyzing Developmental Change." Developmental Psychology, 11(6):738-748. http://dx.doi.org/10.1037/0012-1649.11.6.738

Rosenberg, M., Schooler, C., \& Schoenbach, C. 1989. "Self-esteem and Adolescent Problems: Modeling Reciprocal Effects." American Sociological Review, 54(6):1004-1008. http://dx.doi.org/10.2307/2095720

Shavelson, R.J., Hubner, J. J., and Stanton, G. C. 1976. "Selfconcept: Validation of Construct Interpretations." Review of Educational Research, 46:407-441. http://dx.doi.org/10.3102/00346543046003407

Shavelson, R. J. 1996. Statistical Reasoning for the Behavioral Sciences. Allyn \& MA: Bacon.

Shaw, J.M., \& Scott, W.A. 1991. "Influence of Parent Discipline Style on Delinquent Behaviour: The Mediating Role of Contro Orientation." Australian Journal of Psychology, 43(2):61-67. http://dx.doi.org/10.1080/00049539108259101

Shek, T. L. 2004. "Chinese Culture Beliefs about Adversity: Its Relationship to Psychological Well-Being, School Adjustment and Problem Behavior in Hong Kong Adolescents with and without Economic disadvantage." Childhood, 11:63-80. http://dx.doi.org/10.1177/0907568204040185

Shin, H. J., \& Yu K. 2012. "Connectedness of Korean Adolescents: Profiles and Influencing Factors." Asia Pacific Educational Review, 13(4):593-605.

Stams, G. J., Brugman, D., Deković, M., van Rosmalen, L., van der Laan, P., \& Gibbs, J. C. 2006. "The Moral Judgment of Juvenile Delinquents: A Meta-analysis." Journal of abnormal child psychology, 34(5):692-708.

http://dx.doi.org/10.1007/s10802-006-9056-5

Sun, C. F., Shek, T. L. 2009. "Life Satisfaction, Positive Youth Development, and Problem Behaviour Among Chinese Adolescents in Hong Kong." Social Indicators Research, 95(3):455-474

http://dx.doi.org/10.1007/s11205-009-9531-9

Tarry, H., \& Emler, N. 2007. "Attitudes, Values and Moral Reasoning as Predictors of Delinquency." British Journal of Developmental Psychology, 25(2):169-183. http://dx.doi.org/10.1348/026151006X113671

The Sun. 2012. Thirteen Year Old Drug Addict Seeking Help. The Sun. Retrieved 25 ${ }^{\text {th }}$ March, 2013, URL: http://thesun.on.cc/cnt/news/20120325/00407_084.html?pubdate=201 20325

Warr, M. 1993. "Age, Peers, and Delinquency." Criminology, 31(1):17-40.

http://dx.doi.org/10.1111/j.1745-9125.1993.tb01120.x 
Wells, L.E., \& Rankin, J.H. 1983. "Self-concept as a Mediating Factor in Delinquency." Social Psychology Quarterly, 46(1):11-22. http://dx.doi.org/10.2307/3033656

Wong, D.S.W, Cheng, C.H.K., Leung, S.O., and Ma, S.K. 2010. "Cognitive and Moral Development of Adolescents: Implications to Law Reform of Minimum Age of Criminal Responsibility." The Journal of Youth Research, 159:24-31.
Wyatt, J. M., \& Carlo, G. 2002. "What Will My Parents Think? Relations among Adolescents' Expected Parental Reactions, Prosocial Moral Reasoning, and Prosocial and Antisocial Behaviors." Journal of Adolescent Research, 17(6):646-666. http://dx.doi.org/10.1177/074355802237468

Received on 11-03-2014

Accepted on 17-04-2014

Published on 24-04-2014

DOI: http://dx.doi.org/10.6000/1929-4409.2014.03.12

(C) 2014 Christopher Cheng; Licensee Lifescience Global.

This is an open access article licensed under the terms of the Creative Commons Attribution Non-Commercial License (http://creativecommons.org/licenses/by-nc/3.0/) which permits unrestricted, non-commercial use, distribution and reproduction in any medium, provided the work is properly cited. 